\title{
Occurrence of Salmonella in Raw Chicken Meat from Retail Equipment and Environments in Southern Nigeria Open Markets
}

\author{
Gideon I. OGU ${ }^{1 *}$, Faith I. AKINNIBOSUN ${ }^{2}$ \\ ${ }^{1}$ Novena University, Department of Biological Sciences, P.M.B. 002, Ogume, Delta State, \\ Nigeria; gideoniogu@gmail.com (correspondingauthor) \\ ${ }^{2}$ University of Benin, Department of Microbiology, P.M.B. 1154, Benin City, Edo State, Nigeria; fakinnibosun@yahoo.co.uk
}

\begin{abstract}
Salmonella species is one of the most significant food-related pathogens of public health concern, whose leading vehicles of transmission to humans are chicken products. Hence, this study investigated the occurrence of Salmonella in chicken meat in correlation to their retailing equipment/environments of open markets located in Warri, Benin City, Akure and Ado-Ekiti metropolis (Southern Nigeria). A total of 680 samples comprising raw chicken carcass ( $\mathrm{n}=240$ muscle tissues), rinsing water $(n=60)$, hovering houseflies $(n=200)$ and swabs from retailing table $(n=60)$, cutting knives $(n=60)$ and meat storage containers $(\mathrm{n}=60)$ were collected and analysed using standard techniques. Salmonella was recovered in 105 samples, presenting a prevalence rate of $15.4 \%$ (105/680). Rinsing water (40.0\%) had the highest rate, followed by chicken carcass and retailing table $(16.7 \%)$, storage containers (18.3\%), hovering flies $(9.0 \%)$, and then cutting knives $(3.3 \%)$. The prevalence of Salmonella was highest in Benin City samples (24.7\%; P<0.05), followed by Warri samples (15.9\%), Ado-Ekiti (11.9\%) and Akure (9.4\%) being the least. The mean Salmonella counts (CFU/mL) per sample revealed that Benin City $\left(0.09 \times 10^{2}-5.49\right.$ $\left.\times 10^{6}\right)$ yielded the highest Salmonella load, followed by Warri $\left(0.00-6.11 \times 10^{5}\right)$, Ado-Ekiti $\left(0.00-5.49 \times 10^{4}\right)$ and Akure $\left(0.00-3.02 \times 10^{4}\right)$. These findings suggest that the occurrence of Salmonella in commercial chicken meat is still high in most of the study locations and the rinsing water, tables and storage containers could be potential transmission routes. Adequate thermal treatment measures are recommended before consummation of commercial chicken meat within the regions.
\end{abstract}

Keywords: enterobacteriaceae; open market; prevalence; poultry; Salmonella

\section{Introduction}

Globally, poultry meat remains one of the vital sources of essential amino acids, proteins, vitamins and minerals, needed in human diet. As a nutritional balanced food, meats are constantly exposed to microbial contaminations during production or processing (Ogu et al., 2017). Though they serve as important food nutrient for humans, studies have shown that consumption of poorly processed chicken meat and products could serve as a veritable route for most human food-borne illnesses (Stoica et al., 2015; USDA, 2015; Nidaullah et al., 2017; Gonçalves-Tenório et al., 2018).

Poultry and other livestock acquire and harbour diverse microbial flora and parasites on their skins, feathers and alimentary tracts. From these locations, pathogens and other parasites of public health concerns may contaminate the meat products during the slaughtering processes (Stoica et al., 2015). Moreover, subsequent contaminations of the meat usually occur during feather plucking, evisceration, washing, storage environment, and unhygienic processing equipment (Bhaisare et al., 2014; Ogu et al., 2017). The major bacterial pathogens reportedly implicated in samples of poultry meat included Salmonella enterica, Campylobacter, Staphylococcus aureus, Shigella sp., Escherichia coli, Listeria, Yersinia enterocolitica, Aeromonas and Clostridium perfringens (De Boer et al., 1991; CDC, 2010; Bhaisare et al., 2014; Gonçalves-Tenório et al., 2018). Among these, researchers have identified the genus Salmonella as the leading cause of most forborne illnesses as well as colossal economic losses globally (USDA, 2015).

The genus Salmonella was first recovered from intestinal samples of infected pigs (classic swine fever) by Theobald Smith in 1855 and colleagues, but was named after the American bacteriologist, D. E. Salmon, a co-worker of Theobald Smith (Arora and Arora, 2014). Although, the 
176

classification and nomenclature of Salmonella is still contentious and developing, currently, the Centres for Disease Control and Prevention (CDC) uses (Popoff et al., 2003; Eng et al., 2015) are adopting the nomenclatural system of Salmonella recommended by the World Health Organization (WHO). By this taxonomic system, the two broad species of the genus Salmonella, based on the 16S rRNA sequence analysis, are Salmonella enterica (type species) and Salmonella bongori (Eng et al., 2015). A further study on their genomic relatedness and biochemical properties, regrouped the type species, $S$. enterica into six subspecies; denoted with roman numerals: I, S. enterica subsp. enterica; II, S. enterica subsp. salamae; IIIa, S. enterica subsp. arizonae; IIIb, S. enterica subsp. diarizonae; IV, S. enterica subsp. houtenae; and VI, S. enterica subsp. indica (Reeves et al., 1989; Hurley et al., 2014; Eng et al., 2015). Among all the subspecies of Salmonella, S. enterica subsp. enterica (I) is found predominantly in mammals and contributes approximately 99\% of Salmonella infections in humans and warm-blooded animals (Hurley et al., 2014). In contrast, the other five Salmonella subspecies and S. bongori are found mainly in the environment and in cold-blooded animals, and hence are rare in humans (Brenner et al., 2000; Hurley et al., 2014; Eng et al., 2015).

The most clinical feature of salmonellosis is gastroenteritis, which is usually self-limiting, but might be invasive and severe, particularly in children, the elderly and immunocompromised patients (Ogu et al., 2017). The ability of Salmonella to cause invasive infection varies with the serovar, the age of patient, and region. Of the over 2,500 known serotypes of Salmonella species, Salmonella enterica serovars Enteritidis and Typhimurium types (the nontyphoidal Salmonella group) remain the most frequently implicated serovars in salmonellosis outbreaks among humans who consume raw or improperly processed animal products such as chicken meat (Panisello et al., 2000; Agada et al., 2014; Eng et al., 2015, Ogu et al., 2017).

Salmonellosis, especially from non-typhoidal Samonella strains, has been traced to numerous sources, but recent reports have narrowed it down to the consumption of poultry and poultry food products (Agada et al., 2014; Akeem et al., 2017). Hence, it is pertinent to constantly monitor the whole of such food products. According to previous reports, the increasing level of human salmonellosis stems from the fact that there is a lack of obvert signs and symptoms in infected host poultry (Patrick et al., 2004; Dawoud et al., 2011). This scenario is worsened by the obvious absence of well regimented national epidemiological surveillance protocol, thereby beclouding the actual understanding of the spreading routes and carriers sources of non-typhoidal Salmonella (Kagambèga et al., 2013; Akeem et al., 2017).

Effective management of infection of Salmonella, therefore, involves a holistic approach by monitoring the contamination status of commercial raw poultry and associated risk factors in and around open marketing systems, which is prevalent in most developing countries, including Nigeria. Most studies in the past have concentrated on the prevalence of Salmonella contamination of poultry farms and production lines (Agbaje et al., 2010; Adesiyun et al., 2014; Agada et al., 2014a; Agada et al., 2014b; Ifeanyichukwu et al., 2016; Akeem et al., 2017; Bashir, 2017; Nidaullah et al., 2017), but recent findings revealed that the prevalence thereby was still at relatively low level when compared to the commercial raw poultry carcass exposed to unhygienic retailing materials and environments because of the improved environmental sanitation, hygiene, disease treatment of most commercial poultry farms (Babatunde et al., 2017). Therefore, this study investigated the occurrence of Salmonella in commercial raw chicken meat from their retailing equipment and environments within some open markets in Southern Nigeria.

\section{Materials and Methods}

\section{Studylocation}

The study locations include four major open markets located in selected major capital cities in and around the Niger Delta region, namely, Effurun main market (Warri metropolis, Delta State), Oja-Oba market, Akure, Ondo State), Oba market (Benin City, Edo State), and Oja-Oba market (Ado-Ekiti, Ekiti State). The study areas are located in the south west (Ondo and Ekiti State) and south south (Delta and Edo States) Nigeria (Fig. 1).

\section{Samples size}

The method of Bashir, 2017 was adopted. The prevalence rate employed was $20 \%$ (Ifeanyichukwu $e t$ al., 2016) and the formula for the sample size determination is shown below (Bashir, 2017):

$\mathrm{N}=\mathrm{PQ} /(\mathrm{E} / \mathrm{Z})^{2}$

Where $\mathrm{N}=$ Number of sample to be collected,

$\mathrm{P}=$ prevalence of previous study 20\% (Ifeanyickukwu et al., 2016),

$\mathrm{Q}=100-\mathrm{p}=100-20=80$

$\mathrm{E}=$ Allowable error $=0.05$

$\mathrm{Z}=$ Standard normal distribution at $95 \%, \mathrm{CI}=$ Confidence interval, 1.96.

From the calculation, using the parameters above, $\mathrm{N}$ was found to be 244 . However, the total of samples collected was 680 .

\section{Sample collection}

The samples were collected using the simple random sampling methods from chicken meat and their retailing equipment/environment. The chicken meat included the muscle tissues, while the retailing equipment/environment included the wooden retailing tables, cutting knives, rinsing water, hovering houseflies (Musca domestica L.) and chicken meat storage containers. For each metal and wooden retailing equipment/environment contact surfaces, 10 - 15 $\mathrm{cm}^{2}$ area was swabbed thoroughly in accordance with the standard microbiological protocol for examination of food (APHA, 1992). A total of 680 samples, comprising raw chicken carcass $(\mathrm{n}=240$ muscle tissues), chicken meat rinsing water source $(n=60)$, hovering house-flies $(n=$ 200) and swabs from retailing table $(\mathrm{n}=60)$, cutting knives $(\mathrm{n}=60)$ and meat storage containers $(\mathrm{n}=60)$ were 


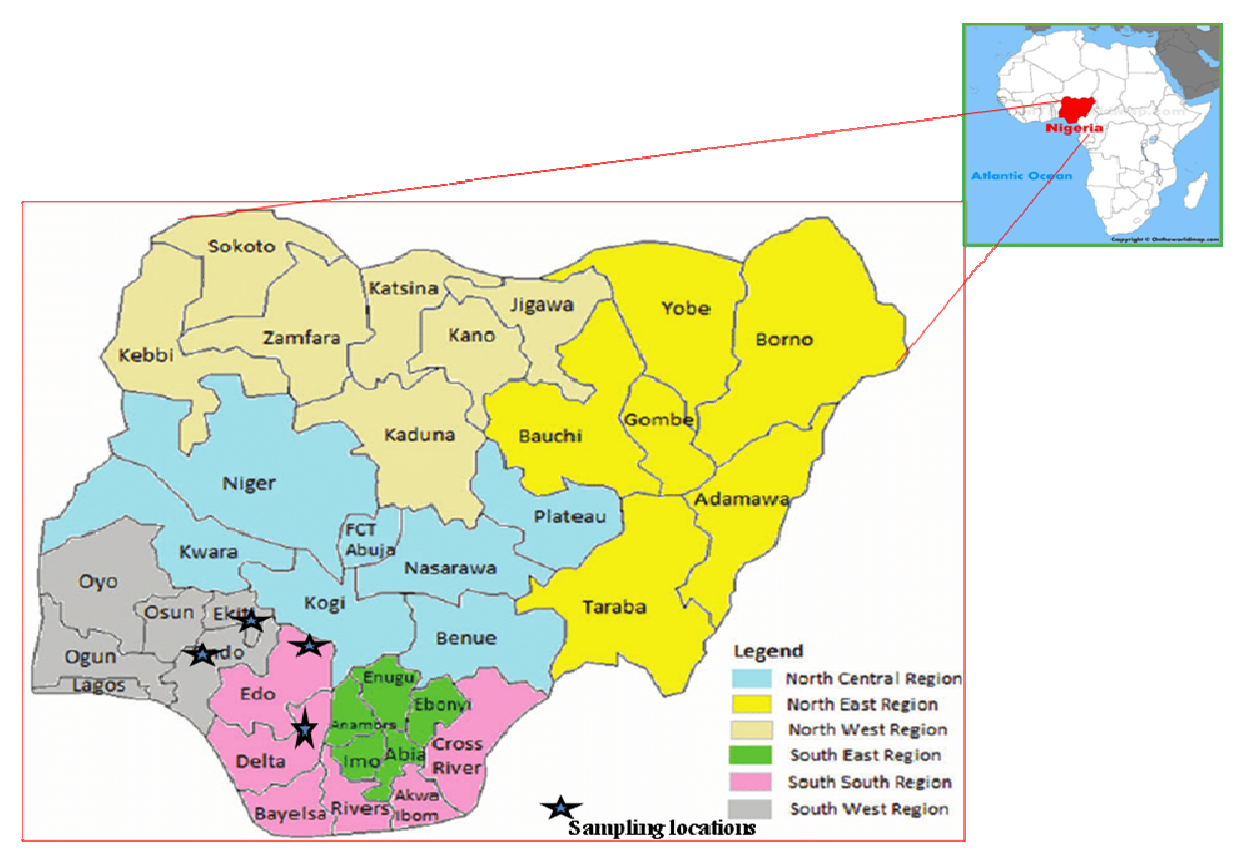

Fig. 1. Map of the sampling locations in Southern Nigeria (Gayawan et al., 2014)

collected from each markets sited within the sampling locations above. The swab heads of the sticks used were rinsed in $10 \mathrm{ml} 0.1 \%$ buffered peptone water (Faleke et al., 2017). The chicken meat were placed in sterile stomacher bags and sealed appropriately. All the samples were conveyed to the laboratory after collection in black polyethylene bags placed within ice packs to maintain the World Health Organization's recommended temperature range of $4{ }^{\circ} \mathrm{C}$ to $6{ }^{\circ} \mathrm{C}$ (WHO, 2010). The sampling was done quarterly between October 2017 to September 2018.

\section{Bacteriological analysis of samples}

$225 \mathrm{ml}$ of sterile $0.1 \%$ Buffered peptone water (Becton and Dickinson, USA) was aseptically added to each chicken meat $(25 \mathrm{~g})$ contained in stomacher bags ( $400 \mathrm{ml}$ capacity) mix thoroughly and allow to stand overnight (preenrichment) in accordance with the standard protocol (ISO 6579: 2002) for microbiological analysis of food and related products. Thereafter, $1 \mathrm{ml}$ was inoculated into a $9 \mathrm{ml}$ of Rapapport-Vassiliadis Soya broth (RVS Himedia ${ }^{\mathrm{TM}}$ ) and incubated overnight at $37^{\circ} \mathrm{C}$. A loopful from the overnight Rapapport Vassiliadis Soya broth culture was aseptically streaked on previously prepared sterile Xylose lysine deoxycholates Agar (XLD Himedia ${ }^{\mathrm{TM}}$ ) and Salmonella Shigella Agar (SS Himedia ${ }^{\mathrm{TM}}$ ) plates and again incubated aerobically overnight $37^{\circ} \mathrm{C}$. The colonies were examined thereafter for suspected typical characteristics representative of Salmonella colonies on XLD, which appeared coloured (red) or colourless with a black centre (Arora and Arora, 2014; Bashir, 2017). The colonies were enumerated from the replicate plates using colony-counting chamber and the mean counts were expressed as colony-forming units (CFU) according to sample type $(\mathrm{mL})$. The typical colonies were then purified using fresh medium before sub-culturing the pure cultures onto sterile agar slants for further bacteriological characterization.

\section{Characterization of pure cultures of Salmonella}

The following tests were performed: Gram reaction, Triple Sugar Fermentation (TSI) test, urease test, citrate utilization test, indole production, Methyl Red test, VogesProskauer test, according to Bashir (2017).

\section{Statistical analysis of data}

All the bacterial counts were expressed as colony forming units $(\mathrm{CFU}) / \mathrm{mL}$ depending on the nature of the samples. Then descriptive statistics was used to express the results as mean and standard deviations of the counts. ANOVA was used to determine the statistical differences of the means counts obtained at level of significance of $p=0.05$.

\section{Results}

Out of the 680 samples investigated, Salmonella was recovered in 105 , presenting a prevalence rate of $15.4 \%$ $(105 / 680)$. A breakdown of the total prevalence with respect to sample types showed that rinsing water $(40.0 \%)$ had the highest rate, followed by chicken carcass and retailing table (16.7\%), storage containers (18.3\%), hovering flies (9.0\%), and then cutting knives (3.3\%) (Fig. 2). With respect to sampling location, the prevalence of Salmonella was highest in Benin City samples $(24.7 \%)(\mathrm{P}<0.05)$, followed by Warri samples (15.9\%), Ado-Ekiti (11.9\%) and Akure (9.4\%) being the least (Fig. 3).

The order of prevalence of Salmonella in Warri samples were; rinsing water $(46.7 \%)>$ chicken carcass $(21.7 \%)>$ retailing table $(13.3 \%)>$ hovering flies $(8.0 \%)>$ storage containers $(8.0 \%)>$ cutting knives $(0.0 \%)$ (Table 1$)$. Similarly, Akure rinsing water samples had the highest Salmonella prevalence (26.7\%), followed by storage containers (20.0\%), chicken carcass (8.3\%), retailing table (6.7\%), hovering flies (4.0\%) and cutting knives (0.0\%) (Table 2). 
In the same vein, a similar trend was observed with the samples from Benin City and Ado-Ekiti (Tables 3 and 4). However, only Benin City samples of cutting knives recorded positive results for Salmonella to the tune of 13.7\% (Table 3). In all, chicken meat alone accounted for $25 \%$ (Benin City, Edo State), 21.7\% (Warri, Delta State), 11.7\% (Ado-Ekiti, Ekiti State) and 8.3\% (Akure, Ondo State) (Tables 1-5).

The bacteriological load of Salmonella in the positive samples were enumerated and found to vary significantly with respect to the sampling locations and types. The results Salmonella counts in the samples are shown in Tables 5-9. The mean counts $(\mathrm{CFU} / \mathrm{mL})$ per samples observed ranged

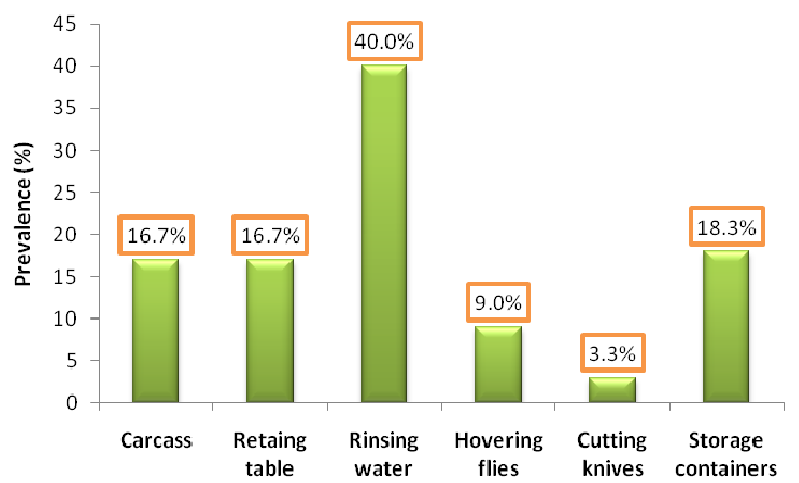

Fig. 2. Overall prevalence rate of Salmonella in different sample types from $0.00-6.11 \times 10^{5}$ (Warri), $0.00-3.02 \times 10^{4}$ (Akure), $0.09 \times 10^{2}-5.49 \times 10^{6}$ (Benin City) and $0.00-5.49 \times 10^{4}$ (Ado-Ekiti). It shows that Benin City yielded the highest Salmonella load, followed by Warri, Ado-Ekiti and Akure samples. The bacterial counts in the chicken meat were significantly $(p<0.05)$ higher in all the samples. Though, the mean counts for the rinsing water samples appears significantly higher in all the samples, they were not statistically different $(p>0.05)$ from those of retailing table, hovering flies and storage containers. Zero counts were however recorded for the all the samples locations for cutting knives, except those from Benin City (Table 7).

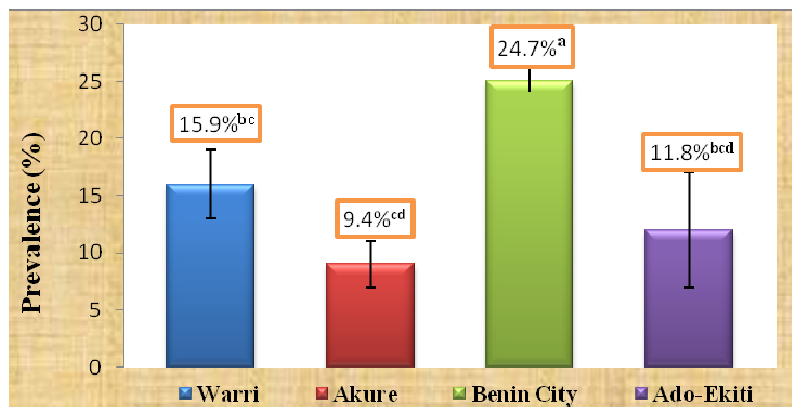

Fig. 3. Overall prevalence of Salmonella species in the chicken and retaining/environments (Values with the same letters are not significantly different at $p=0.05$ )

Table 1. Prevalence of Salmonella in chicken meat and retailing materials/environment of Effurun market, Warri Delta State

\begin{tabular}{|c|c|c|c|}
\hline Locations & Number of samples & Number of positive samples & Prevalence $(\%)$ \\
\hline Carcass & 60 & 13 & 21.7 \\
\hline Retailing table & 15 & 2 & 13.3 \\
\hline Rinsing water & 15 & 7 & 46.6 \\
\hline House-Flies & 50 & 4 & 8.0 \\
\hline Cutting knives & 15 & 0 & 0.0 \\
\hline Storage container & 15 & 1 & 6.7 \\
\hline Overall & 170 & 27 & 15.9 \\
\hline
\end{tabular}

Table 2. Prevalence of Salmonella in chicken meat and retailing materials/environment of Oja-Oba Market, Akure, Ondo State

\begin{tabular}{|c|c|c|c|}
\hline Locations & Number of samples & Number of positive samples & Prevalence $(\%)$ \\
\hline Carcass & 60 & 5 & 8.3 \\
\hline Retailing table & 15 & 2 & 13.3 \\
\hline Rinsing water & 15 & 4 & 26.7 \\
\hline House-Flies & 50 & 2 & 4.0 \\
\hline Cutting knives & 15 & 0 & 0.0 \\
\hline Storage container & 15 & 3 & 20.0 \\
\hline Overall & 170 & 16 & 9.4 \\
\hline
\end{tabular}

Table 3. Prevalence of Salmonella in chicken meat and retailing materials/environment of Oba market, Benin City, Edo State

\begin{tabular}{cccc}
\hline Locations & Number of samples & Number of positive samples & Prevalence (\%) \\
\hline Carcass & 60 & 15 & 4 \\
Retailing table & 15 & 9 & 25.0 \\
Rinsing water & 15 & 7 & 60.0 \\
House-Flies & 50 & 2 & 14.0 \\
Cutting knives & 15 & 5 & 13.7 \\
Storage container & 15 & 42 & 33.3 \\
Overall & 170 & 24.7 \\
\hline
\end{tabular}


Table 4. Prevalence of Salmonella in chicken meat and retailing materials/environment of Oja-Oba market, Ado-Ekiti, Ekiti State

\begin{tabular}{cccc}
\hline Locations & Number of samples & Number of positive samples & Prevalence (\%) \\
\hline Carcass & 60 & 7 & 11.7 \\
Retailing table & 15 & 2 & 13.3 \\
Rinsing water & 15 & 4 & 26.7 \\
House-Flies & 50 & 5 & 10.0 \\
Cutting knives & 15 & 0 & 0.0 \\
Storage container & 15 & 2 & 13.3 \\
Overall & 170 & 20 & 11.8 \\
\hline
\end{tabular}

Table 5. Mean counts of Salmonella in chicken meat and retailing materials/environment of Effurun market, Warri Delta State

\begin{tabular}{cccc}
\hline Locations & Minimum counts & Maximum counts & Mean \pm SD $(\mathrm{CFU} / \mathrm{mL})^{*}$ \\
\hline Carcass & $2.34 \times 10^{2} \pm 2.59$ & $5.09 \times 10^{6} \pm 2.03$ & $6.11 \times 10^{5} \pm 1.64^{\mathrm{a}}$ \\
Retailing table & 0.00 & $1.22 \times 10^{2} \pm 7.07$ & $0.81 \times 10^{2} \pm 6.03^{\mathrm{b}}$ \\
Rinsing water & $3.12 \times 10^{2} \pm 4.22$ & $5.05 \times 10^{4} \pm 0.08$ & $9.12 \times 10^{3} \pm 0.89^{\mathrm{b}}$ \\
Hovering flies (Musca domestica) & 0.00 & $8.11 \times 10^{2} \pm 7.31$ & $0.89 \times 10^{2} \pm 9.51^{\mathrm{b}}$ \\
Cutting knives & 0.00 & 0.00 & $0.00^{\mathrm{b}}$ \\
Storage container & $0.62 \times 10^{2} \pm 0.09$ & $3.66 \times 10^{3} \pm 2.51$ & $1.02 \times 10^{2} \pm 1.88^{\mathrm{b}}$ \\
\hline
\end{tabular}

$\left({ }^{*}\right.$ Results are mean counts of three replicate values; values with same letters are not significantly different at $\left.p=0.05\right)$

Table 6. Mean counts of Salmonella in chicken meat and retailing materials/environment of Oja-Oba Market, Akure, Ondo State

\begin{tabular}{cccc}
\hline Locations & Minimum counts & Maximum counts & Mean $\pm \mathrm{SD}(\mathrm{CFU} / \mathrm{mL})^{*}$ \\
\hline Carcass & $5.06 \times 10^{2} \pm 1.09$ & $4.21 \times 10^{5} \pm 1.04$ & $3.02 \times 10^{4} \pm 4.11^{\mathrm{a}}$ \\
Retailing table & $0.18 \times 10^{1} \pm 2.09$ & $4.73 \times 10^{2} \pm 0.55$ & $1.81 \times 10^{1} \pm 0.03^{\mathrm{bc}}$ \\
Rinsing water & $2.92 \times 10^{1} \pm 4.22$ & $1.02 \times 10^{3} \pm 2.22$ & $6.25 \times 10^{2} \pm 2.35^{\mathrm{ab}}$ \\
Hovering flies (Musca domestica) & 0.00 & $0.78 \times 10^{2} \pm 3.31$ & $0.21 \times 10^{2} \pm 0.99^{\mathrm{bc}}$ \\
Cutting knives & 0.00 & 0.00 & $0.00^{\mathrm{d}}$ \\
Storage container & 0.00 & $8.23 \times 10^{3} \pm 2.09$ & $1.02 \times 10^{2} \pm 6.01^{\mathrm{b}}$ \\
\hline
\end{tabular}

$\left({ }^{*}\right.$ Results are mean counts of three replicate values; values with same letters are not significantly different at $\left.p=0.05\right)$

Table 7. Mean counts of Salmonella in chicken meat and retailing materials/environment of Oba market, Benin City, Edo State

\begin{tabular}{cccc}
\hline Locations & Minimum counts & Maximum counts & Mean \pm SD $(\mathrm{CFU} / \mathrm{mL})^{*}$ \\
\hline Carcass & $4.11 \times 10^{2} \pm 3.02$ & $6.42 \times 10^{7} \pm 2.77$ & $5.49 \times 10^{6} \pm 5.99^{\mathrm{a}}$ \\
Retailing table & $1.73 \times 10^{2} \pm 0.02$ & $9.40 \times 10^{3} \pm 4.85$ & $2.62 \times 10^{2} \pm 6.33^{\mathrm{b}}$ \\
Rinsing water & $1.03 \times 10^{2} \pm 8.12$ & $1.99 \times 10^{3} \pm 2.22$ & $5.04 \times 10^{3} \pm 2.05^{\mathrm{b}}$ \\
Hovering flies (Musca domestica) & $0.09 \times 10^{1} \pm 4.22$ & $1.59 \times 10^{2} \pm 0.34$ & $1.01 \times 10^{2} \pm 0.04^{\mathrm{b}}$ \\
Cutting knives & 0.00 & $0.88 \times 10^{1} \pm 0.82$ & $0.09 \times 10^{2} \pm 4.80^{\mathrm{bc}}$ \\
Storage container & $0.99 \times 10^{1} \pm 0.52$ & $4.33 \times 10^{3} \pm 1.51$ & $6.72 \times 10^{2} \pm 2.23^{\mathrm{b}}$ \\
\hline
\end{tabular}

$\left({ }^{*}\right.$ Results are mean counts of three replicate values; values with same letters are not significantly different at $\left.p=0.05\right)$

Table 8. Mean counts of Salmonella in chicken meat and retailing materials/environment of Oja-Oba market, Ado-Ekiti, Ekiti State

\begin{tabular}{cccc}
\hline Locations & Minimum counts & Maximum counts & Mean \pm SD $(\mathrm{CFU} / \mathrm{mL})^{*}$ \\
\hline Carcass & $9.28 \times 10^{1} \pm 0.02$ & $5.25 \times 10^{5} \pm 2.05$ & $5.49 \times 10^{4} \pm 1.41^{\mathrm{a}}$ \\
Retailing table & 0.00 & $3.02 \times 10^{1} \pm 4.85$ & $1.25 \times 10^{1} \pm 2.11^{\mathrm{b}}$ \\
Rinsing water & $0.08 \times 10^{2} \pm 8.12$ & $0.95 \times 10^{2} \pm 1.51$ & $0.59 \times 10^{2} \pm 3.33^{\mathrm{b}}$ \\
Hovering flies (Musca domestica) & 0.00 & $0.37 \times 10^{2} \pm 1.22$ & $0.99 \times 10^{1} \pm 4.7^{\mathrm{b}}$ \\
Cutting knives & 0.00 & 0.00 & $0.00^{\mathrm{c}}$ \\
Storage container & $0.24 \times 10^{1} \pm 8.12$ & $1.78 \times 10^{2} \pm 1.51$ & $0.46 \times 10^{2} \pm 5.11^{\mathrm{b}}$ \\
\hline
\end{tabular}

( ${ }^{*}$ Results are mean counts of three replicate values; values with same letters are not significantly different at $\left.p=0.05\right)$

\section{Discussion}

Salmonella infections still remains a global issue with an annual incidence rate of 93.8 million cases and 155,000 deaths per year (Eng et al., 2015; CDC, 2016; Khan et al., 2018). The extent of the burden of this foodborne disease is globally under-reported, but the challenges are more pronounced in developing countries because of very poor documentation of reported cases of human salmonellosis (Barbour et al., 2015). Humans and animals are constantly exposed to these bacteria via various sources. To date, poultry products, particularly chicken products remain the key source of transmission to humans (Khan et al., 2018). Hence, the needs to continue the investigation of 
180

commercial chicken meat and associated retailing, with a view augmenting the currently available information within developing countries.

In this study, the occurrence of Salmonella species in commercial chicken carcass, retailing tables, storage containers, knives, rinsing water and hovering flies, were investigated in four States (Delta, Edo, Ondo and Ekiti) within Southern Nigeria. Salmonella was isolated from all the analyzed samples. The overall prevalence rate obtained in the four States we studied was $15.4 \%(105 / 680)$. This supports earlier studies on the claims that poorly processed/handled chicken meat is often contaminated by Salmonella (Adeyanju and Ishola, 2014; Faleke et al., 2017; Balakrishnan et al., 2018). There were significant differences in the levels of contamination in the various samples with respects to the different locations. From our findings, rinsing water for the chicken meat had the highest level of contamination, while cutting knives were the least. This finding underscores the importance of clean/potable water by retailers for processing of raw chicken carcasses, to reduce the level contaminations by Salmonella and other water borne pathogens of public health significance. A very recent study in Lusaka, Zambia, identified the water used for processing chickens as one of the major risk factors of pathogenic bacterial contaminations (Mpundu et al., 2019). Hence, the recovery of Salmonella from rinsing water, retailing table, knives and storage containers highlights the unhygienic retailing conditions in which raw chicken carcases are exposed to at most open markets in the study locations. Our finding on the low occurrence of Salmonella in cutting knives contradicts some earlier reports (Nidaullah et al., 2017). Another important finding from our study was the prevalence rate of Salmonella in hovering flies at the sampling locations. Previous studies showed the isolation potential of pathogenic microorganisms, including Salmonella, from domestic flies and flies are well documented as major vectors for pathogen transmission (Olsen and Hammack, 2000; Ugbogu, et al., 2006; Choo et al., 2011). The occurrence of Salmonella in the domestic flies hovering around the retailing tables of the chicken carcass is therefore of public health concern, too.

Our results also revealed that the contamination of chicken carcass by Salmonella varied significantly in each of the sampling location. The highest level of contamination was observed with the samples from Benin City (25\%), followed by Warri (21.7\%), Ado-Ekiti (11.7\%), and Akure (8.3\%). This finding is in agreement with earlier reports that contamination of poultry meat varies within and between different countries, globally ( $\mathrm{Ta}$ et al., 2012; Barbour et al., 2015). The prevalence we obtained were closed to those of 23.1\% from Sokoto Main Market and abattoir (Faleke et al., 2017), while those from Warri samples were in line with $11.1 \%$ obtained from Calabar Metropolis (Ukut et al., 2010), both in Nigeria. Other prevalence rates reported in Nigeria included 2.0\% from Osogbo market (Adesiji et al., 2011), 6.5\% reported from Sokoto Metropolis (Garba et al., 2017), 17\% from River State (Omorodion and Odu, 2016). Internationally, the reported prevalence of Salmonella in commercial raw chicken meat was 5\% in Egypt (Tarabees $e t$ al., 2017), 17.41\% in Tolima, Colombia (Rodriguez et al., 2015), and 23.7\% in Patna, India (Kaushik et al., 2014).
Higher occurrences were, however, reported in Tamil Nadu (33.3\%) (Balakrishnan et al., 2018), 53.3\% in Vietnam (Van et al., 2007) and $41.6 \%$ - 54\% in China (Yang et al., 2010; Zhu et al., 2014). The differences observed could be attributed to differences in the levels of processors/retailers' hygiene, environmental sanitations, marketing conditions, sampling methods and protocols of analysis. Similar observations were done by other authors (Adeyanju and Ishola, 2014; Rodriguez et al., 2015).

Furthermore, Salmonella counts also varied significantly in relation to the sample types and locations. The highest counts were found in chicken samples, which was significantly different from rest of the samples. This finding is in consonance with the study of Omorodion, and Odu (2016), who reported a total Salmonella count of $1.09 \times 10^{6}$ $-4.98 \times 10^{6}(\mathrm{CFU} / \mathrm{mL})$. It also corroborates with earlier findings that raw chicken meat are good substrate and vehicle for the transmission of Salmonella and other enteric pathogens (Brown, 2000). Additionally, this finding suggests that chicken meat retailed in unhygienic environment, such as open markets, could be a potential reservoir for Salmonella. Therefore, the observed level of Salmonella was attributed to the lack of proper personal hygienic measures / disinfection of retailing / storage equipment's coupled with poor environmental sanitations prevalent in most of the open markets within the study locations. Hence, proper handling of raw chicken meat is encouraged to prevent Salmonella contaminations.

\section{Conclusions}

This study has shown that the occurrence of Salmonella in chicken meat retailed in some open markets in Southern Nigeria is still high and varies with the locations. It has also shown that rinsing water and retailing tables/surfaces for chicken meat carry significant risks of contaminating the meat and environment with Salmonella. Hence, these findings will provide additional information on the hygienic status of commercial raw chicken carcasses and associated factors within the study locations. This is essential for proactive development of appropriate education for the retailers and the public against Salmonella in chicken carcass and its associated transmission routes to prevent possible infections. Moreover, adequate thermal treatment measures are recommended before chicken meat consumption.

\section{Conflicts of interest}

The authors declare that there are no conflicts of interest related to this article.

\section{References}

Adesiyun A, Webb L, Musai L, Louison B, Joseph G, Johnson A, ... Rodrigo $S$ (2014). Survey of Salmonella contamination in chicken layer farms in three Caribbean countries. Journal of Food Protection 77(9):14711480.

Agada GA, Abdullahi IO, Aminu M, Odugbo M, Chollom SC, Okeke LA, Okwori AEJ (2014a). Prevalence and risk factors associated with 
Salmonella species contamination of commercial poultry farms in Jos, Plateau State, Nigeria. World Journal of Biology and Biological Science 2(3):49-61.

Agada GO, Abdullahi IO, Aminu M, Odugbo M, Chollom SC, Kumbish PR, OkworiAEJ (2014b). Prevalence and antibiotic resistance profile of Salmonella isolates from commercial poultry and poultry farmhandlers in Jos, Plateau State, Nigeria. British Microbiology Research Journal 4(4):462-479.

Agbaje M, Davies R, Oyekunle MA, Ojo OE, Fasina FO, Akinduti PA (2010). Observation on the occurrence and transmission pattern of Salmonella gallinarum in commercial poultry farms in Ogun State, South Western Nigeria. African Journal Microbiological Research (9):796-800.

Akeem AO, Mamman PO, Raji A, Kwanashie CN, Raufu IA, Aremu A (2017). Distribution of virulence genes in Salmonella serovars isolated from poultry farm in Kwara State, Nigeria. Ceylon Journal of Science 46(4):69-76.

American Public Health Association (1992). Compendium of methods for the microbial examination of foods. 3rd rev. ed. Vanderzant C, Stoesser SplittDF, Washington DC, USA pp 423-431.

Babatunde SK, Kolawole DO, Adedayo M, Ajiboye AE, Ajao AT, Mustapha ON (2017). Prevalence and characterization of Salmonella isolates from poultry farms in Ilorin, Nigeria. Journal of Life Sciences Research 4(1):1-4.

Balakrishnan S, Sangeetha A, Dhanalakshmi M (2018). Prevalence of Salmonella in chicken meat and its slaughtering place from local markets in Orathanadu, Thanjavur district, Tamil Nadu. Journal of Entomology andZoology Studies 6(2):2468-247.

BarbourEK, Ayyash DB, Alturkistni W, Alyahiby A, Yaghmoor S, Iyer A, ... Harakeh S (2015). Impact of sporadic reporting of poultry Salmonella serovars from selected developing countries. Journal of Infection Diseases ofDeveloping Countries 9(1):1-7.

Bashir M (2017). Isolation and molecular detection of antibiotic resistant Salmonella species from some poultry farms in southern part of Katsina State, Nigeria. ADissertation submitted to the School of Postgraduate Studies, Ahmadu Bello University, Zaria. Partial Fulfilment of the Requirement for the Award of a Master of Science Degree in Microbiology Department of Microbiology, Faculty of Life Sciences, Ahmadu Bello University,Zariapp 38.

Brown MH (2000). Processed meat products. In: The microbiological safety and quality of food. Aspen Publishers, Gaithersburg,pp 389-419.

CDC (2016). CDC (Center for Disease Control) - Health information for Travel 2016. New York: Oxford University Press pp1-688.

Choo LC, Saleha AA, Wai SS, Fauziah N (2011). Isolation of Campylobacter and Salmonella from houseflies (Musca domestica) in a university campus and a poultry farm in Selangor, Malaysia. Tropical Biomedicine28(1):16-20.

Dawoud TM, Hererra P, Hanning I, Kwon YM, Ricke SC (2011). In vitro invasion oflaying hen ovarian follicles by Salmonella Enteritidis strains. PoultryScience 90(5):11341137.

Eng S-K, Pusparajah P, Mutalib N-S, Ser H-L, Chan K-G, Lee L-H (2015). Salmonella: A review on pathogenesis, epidemiology antibiotic resistance. Frontiers in Life Science 8(3):284-293.
Faleke OO, Jolayemi KO, Igoh YO, Jibri AH, Ayedun JO (2017) Salmonella species on meat contact surfaces and processing water in Sokoto main market and abattoir Nigeria. Macedonian Veterinary Review 40(1):59-65.

Garba MK, Olonitola OS, Yakubu SE, Abdullahi IO (2017). Antimicrobial susceptibility and occurrence of resistance genes among Salmonella arizonae isolated from chicken meat samples in Sokoto Metropolis Sokoto State, Nigeria. UMYU Journal of Microbiology Research 2(2):71-76.

Gayawan E, Arogundade ED, Adebayo SB (2014). Possible determinants and spatial patterns of anaemia among young children in Nigeria: a Bayesian semi-parametric modelling. International Health 6:35-45.

Gonçalves-Tenório A, Silva BN, RodriguesV, Cadavez V, Gonzales-Barron U (2018). Prevalence of pathogens in poultry meat: A meta-analysis of European published surveys. Foods 7:69.

Gould LH, Walsh KA, Vieira AR, Herman K, Williams IT, Hall AJ, Cole D (2013). Surveillance for foodborne disease outbreaks -United States, 1998-2008. Morbidity and Mortality Weekly Reports 62(02):1-34.

Ifeanyichukwu I, ChikaE, Ogonna O, Chidinma I, Monique A, Ikechukwu M, ... Agabus N (2016). Prevalence and antibiogram of Salmonella species isolated from poultry products in Ebonyi State, Nigeria. Journal of Advanced Veterinary and Animal Research 3(4):353-359.

Kagambèga A, Lienemann T, Aulu L, Traoré AS, Barro N, Siitonen A (2013). Prevalence and characterization of Salmonella enterica from the feces of cattle, poultry, swine and hedgehogs in Burkina Faso and their comparison to human Salmonella isolates. BMC Microbiology 13:253.

Kaushik P, Anjay KS, Bharti SK, Dayal S (2014). Isolation and prevalence of Salmonella from chicken meat and cattle milk collected from local markets of Patna, India. Veterinary World 7(2):62-65.

Khan AS, Georges K, Rahaman S, Abdela W, Adesiyun AA (2018). Prevalence and serotypes of Salmonella spp. on chickens sold at retail outlets in Trinidad. PLoS One 13(8):e0202108.

Mpundu P, Mbewe AR, Muma JB, Zgambo J, Munyeme M (2019). Evaluation of bacterial contamination in dressed chickens in Lusaka Abattoirs. Frontiers in Public Health 7:19.

Nidaullah H, Abirami N, Shamila-Syuhada AK, Chuah LO, Nuru H, Tan TP, ... Rusu G (2017). Prevalence of Salmonella in poultry processing environments in wet markets in Penang and Perlis, Malaysia. Veterinary World 10(3):286-292.

Ogu GI, Madar IM, Igborgbor JC, OkoloJC (2017). Mycological quality of freshandfrozen chicken meat retailed within Warri Metropolis, DeltaState,Nigeria.Jordan Journal of Biological Science 10(4):303-308.

Olsen AR, Hammack TS (2000). Isolation of Salmonella spp. from the housefly, Musca domestica L., and the dump fly, Hydrotaea aenescens (Wiedemann) (Diptera: Mucidae) at caged-layer houses. Journal of FoodProtection 63(7):958-60.

Omorodion NJP, Odu NN (2016). Incidence of Salmonella species in commercially processed chicken meat sold in River State, Nigeria. Researcher 8(4):59-64.

Patrick ME, Adcock PM, Gomez TM, Altekruse SE, Holland BH, Tauxe RV, Swendlow DL (2004). Salmonella enteritidis infections, United States, 1985-1999. Emerging Infectious Diseases 10(1):1-7.

PopoffMY, Bockemühl J, GheeslingLL(2003). Supplement 2001 (no. 45) 
182

to the Kauffmann-White scheme. Research in Microbiology 154:173174.

Rodriguez JM, Rondón I, Verjan N (2015). Serotypes of Salmonella in broiler carcasses marketed at Ibague, Colombia. Brazilian Journal of PoultryScience 17(4):545-552.

Sofos JN (2014). Meat and meat products. In: Food Safety Management. Elsevier Inc., Oxford pp 119-162.

Stoica M, Stoean S, Alexe P (2014). Overview of biological hazards associated with the consumption of the meat products. Journal of Agro-alimentary Processes and Technologies 20(2):192-197.

Ta YT, Nguyen TT, To PB, Pham DX, LeHTH, Alali WQ,... Doyle MP (2012). Prevalence of Salmonella on chicken carcasses from retail markets in Vietnam. Journal of Food Protection 75(10):1851-1854.

Tarabees R, Elsayed MSA, Shawish R, Basiouni S, Shehata AA (2017). Isolation and characterization of Salmonella enteritidis and Salmonella typhimurium from chicken meat in Egypt. Journal of Infection in DevelopingCountries 11(4):314319.

Ugbogu OC, Nwachukwu NC, Ogbuagu UN (2006). Isolation of Salmonella and Shigella species from house flies (Musca domestica L.) in
Uturu, Nigeria. African Journal of Biotechnology 5(11):1090-1091.

USDA (United States Department of Agriculture) (2015). Economic Research Service. Accessed on 15 August 2018 at https://www.ers.usda.gov/data-products/.

Van TTH, Moutafis GM, Istivan T, Tran LT, Peter J, Coloe PJ (2007). Detection of Salmonella spp. in retail raw food samples from Vietnam and characterization of their antibiotic resistance. Applied and Environmental Microbiology73(21):6885-6890.

WHO (World Health Organization) (2010). Laboratory protocol. In: Isolation of Salmonella spp. From food and animal faeces, 5th edn. http://antimicrobialresistance.dk/CustomerData/Files/Folders/6-pdfprotocols/63_18-05-isolation-of-salm-220610.pdf.

Yang B, Qu D, Zhang X, Shen J, Cui S, Shi Y, ... MengJ (2010). Prevalence and characterization of Salmonella serovars in retail meats of marketplace in Shaanxi, China. International Journal of Food Microbiology 141(1):63-72.

Zhu J, Wang Y, Song X, Cui S, Xu H, Yang B, ... Li F (2014). Prevalence and quantification of Salmonella contamination in raw chicken carcasses at the retail in China. Food Control 44:198-202. 